\title{
A Non-Adaptive Displacement-based Pushover Procedure for the Nonlinear Static Analysis of Tall Building Frames
}

\author{
Mohamad Amin Amini and Mehdi Poursha* \\ Department of Civil Engineering, Sahand University of Technology, Tabriz, Iran
}

\begin{abstract}
In order to account for the effect of higher modes in estimating the seismic demands of tall buildings, a non-adaptive displacement-based pushover (NADP) procedure based on structural dynamics theory is presented in this paper. The procedure utilizes some single-run conventional and enhanced pushover analyses. The single-run conventional pushover analysis is carried out using a displacement-based load pattern according to the first mode shape, whereas the singlerun enhanced pushover analyses are performed by employing the lateral load distributions obtained by combining the modal story displacements. The modal story displacements are algebraically added; therefore, the signs of modal displacement vectors are retained and the sign reversals in the lateral load distributions are included. Since the NADP is performed in a nonadaptive framework, it does not require more computational effort and time cost. Furthermore, a new method for the determination of the target displacement for tall buildings is proposed using the response spectrum analysis (RSA). To evaluate the NADP procedure, three steel momentresisting frames with different heights as well as a 9-story SAC building frame were selected. The seismic demands resulting from the NADP procedure were compared to those from the nonlinear response history analysis (NL-RHA) as a benchmark solution, as well as to those predicted by the modal pushover analysis (MPA) and displacement-based adaptive pushover (DAP) procedures. The results demonstrate that the NADP procedure can accurately estimate the seismic demands at the upper stories of tall buildings in which the effect of higher modes is substantially significant.
\end{abstract}

Keywords Non-adaptive displacement-based pushover; Higher modes effect; Lateral displacement distribution; Tall buildings

\section{Introduction}

Nonlinear response history analysis (NL-RHA) is the most accurate analytical procedure to estimate the seismic demands of structures responding in the nonlinear range. However, this procedure is relatively complicated and time-consuming. On the other hand, the nonlinear static procedure (NSP) or pushover analysis is widely used as a suitable tool for the seismic performance evaluation of building structures (ASCE/SEI 41-06). Earlier versions of pushover methods presented in various codes (FEMA 356; CEN 2003; ATC-40), are limited to the first-

\footnotetext{
* Correspondence to Mehdi Poursha, Email: Poursha@sut.ac.ir
} 
mode-dominated structures, and they can not take the effect of higher modes into consideration (Krawinkler and Seneviratna 1998; Chopra and Goel 2002). Therefore, much research effort has been devoted in recent years to the development of enhanced pushover procedures to consider the effect of higher modes.

Chopra and Goel (2002, 2004) proposed the modal pushover analysis (MPA) based on structural dynamics theory. This method uses an invariant modal lateral force distribution for implementing the pushover analysis for each mode, and the results obtained for each mode are combined with an appropriate modal combination rule. Plastic hinge rotations derived from this method are greatly underestimated at the upper stories of tall buildings, even if a large number of modes are included (Chopra and Goel 2002; Poursha et al. 2009, 2010). A modified version of the MPA (MMPA) was proposed by Chopra et al. (2004), wherein the response contributions of higher vibration modes were computed with the assumption that the building remains linearly elastic. About the same time, an upper-bound pushover analysis procedure (Jan et al. 2004) was developed in which the upper-bound of the contribution ratio of the second mode in computing the lateral force distribution was used. In another investigation, the mass proportional pushover procedure (MMP) was proposed by Kim and Kurama (2008) without any modal combination. In this method, the effect of higher modes is lumped into a single invariant lateral force distribution that is proportional to the total seismic masses at the floor and roof levels.

Later on, the consecutive modal pushover (CMP) procedure was proposed by Poursha et al. $(2009,2011,2014)$ to take higher modes effect into account. Multi-stage and single-stage pushover analyses are utilized in this procedure. The final responses are estimated by enveloping the results obtained from the multi-stage and single-stage pushover analyses. In another study, Kreslin and Fajfar (2011) extended the N2 method (Fajfar 2000) to take the effect of higher modes into account. The basic assumption is that the structure remains in the elastic range in higher vibration modes. In this method, the seismic demands are determined by enveloping the results of basic pushover analysis and those from elastic modal analysis. The estimation of plastic hinge rotations was not demonstrated with the aid of the EN2 method. About the same time, a generalized pushover analysis (GPA) procedure (Sucuoglu and Selim Gunay 2011) was proposed, in which a set of pushover analyses was carried out by using different generalized force vectors. Each generalized force vector is obtained as a different combination of modal forces in order to simulate the effective lateral force distribution when the inter-story drift at a selected story reaches its maximum value during response history. Finally, the maximum value of a seismic response is obtained by enveloping the values produced by the GPAs.

More recently, a single-run multi-mode pushover (SMP) analysis (Poursha and Amini 2015) was proposed to account for the effect of higher modes in estimating the seismic demands of tall buildings. In this procedure, the effect of higher modes is concentrated into a single invariant lateral force distribution computed by algebraically adding the modal story forces whereby a single-run multi-mode pushover analysis is implemented. An important advantage of the SMP procedure is that the sign reversal in the story forces of higher modes is taken into account. The accuracy of some enhanced nonlinear static procedures in estimating deformation demands of regular and irregular steel moment-resisting frames was investigated by Ferraioli et al. (2014).

All of the above-mentioned enhanced pushover procedures are force-based pushover analyses. However, because of the present tendency for the development and implementation of displacement-based design and assessment methods, it would seem that applying displacement loading, rather than force actions, in pushover methods would be theoretically a proper option for 
the nonlinear static analysis of structures (Antoniou and Pinho 2004b; Pecker 2007). Therefore, attempts have been made to develop displacement-based pushover procedures in recent years.

Antoniou and Pinho (2004b) developed a displacement-based version, called displacementbased adaptive pushover (DAP), as the counterpart of their force-based adaptive pushover (FAP) procedure (Antoniou and Pinho 2004a) to improve the prediction of seismic demands of building structures. In the FAP method, the lateral load pattern is calculated at each step by combining the story forces of each vibration mode using an appropriate combination rule. However, because of implementing a quadratic modal combination rule to combine the modal loads, the effect of sign reversal in the higher modes forces is not taken into consideration in the applied load pattern. Therefore, the DAP procedure was developed in which at each step a displacement loading is applied rather than force actions. In this method, the story forces are calculated as a response of the applied displacement loads and the reversal of sign in the story force profile can be taken into account. Seismic demands of the structures predicted by the DAP procedure were better than those from the FAP (Antoniou and Pinho 2004b).

Recently, a displacement-based adaptive modal pushover method, called APAM, was developed that is based on effective modal mass combination rule (Abbasnia et al. 2013). In this combination rule, a modification factor associated with each mode is applied to the corresponding load vector. The modified modal load vectors are algebraically added and subtracted, and give a range of load patterns. These load patterns are independently applied to the structure within an adaptive framework and the seismic demands are determined by enveloping the demand values obtained from different pushover analyses.

These displacement-based pushover procedures may provide accurate seismic responses; nevertheless, because of their adaptive nature, an eigenvalue analysis is required to be implemented at each loading increment. Therefore, they require more computational effort and time cost. Moreover, only lateral displacements as well as story drifts were estimated by using the DAP and APAM methods, and the prediction of plastic hinge rotations has not been examined with the aid of these methods. It is important to note that in another research the last version of the MPA method (Reyes and Chopra 2011) was introduced in which a non-adaptive displacement-based pushover analysis was employed to estimate plastic hinge rotations from the story drifts. For this purpose, a set of displacements compatible with the calculated story drifts is applied at the center of mass of the building.

The main objective of the present study is to develop a non-adaptive displacement-based pushover (NADP) procedure to take higher modes effect into consideration in estimating the seismic responses of tall building frames. In this new procedure, the seismic demands are calculated by enveloping the results obtained from two or three single-run displacement-based pushover analyses. The major simplification of this method is that the effect of higher modes is concentrated into a single invariant lateral displacement distribution as a load pattern. Consequently, only single-run non-adaptive pushover analyses are sufficient without any need to apply a modal combination rule to the results. An advantage of the proposed method is that the spectral displacement of ground motions is incorporated into the lateral load distribution. Moreover, the NADP procedure not only reduces the computational cost compared to adaptive pushover analyses, but also can provide an accurate prediction of seismic demands at the upper stories of tall buildings. In the present study, a new method for the determination of the target displacement in pushover analysis of tall buildings is also proposed. The NADP method is verified for four steel moment-resisting frames. The seismic demands obtained by the NADP 
procedure are compared with those from the NL-RHA as the most accurate method of seismic demand evaluation, as well as with those predicted from the MPA and DAP procedures.

\section{Proposed pushover procedure}

This section presents a non-adaptive displacement-based pushover procedure to evaluate the seismic demands of tall building frames. In the following, the basic principles of the proposed procedure are described.

\subsection{The conceptual basis of modal response analysis}

The differential equations governing the response of a multi-degree-of-freedom (MDOF) system to earthquake-induced ground motion are given by (Chopra 2001):

$m \ddot{u}+c \ddot{i}+\boldsymbol{k u}=-m i \ddot{u}_{g}(t)$

where $\boldsymbol{m}, \boldsymbol{c}$, and $\boldsymbol{k}$ are the mass, damping, and stiffness matrices of the structure, respectively, and $\boldsymbol{i}$ is the unit vector. The floor displacements of an $N$-degree-of-freedom system can be defined as:

$\boldsymbol{u}(\boldsymbol{t})=\sum_{n=1}^{N} \boldsymbol{\Phi}_{n} q_{n}(t)$

where, $\boldsymbol{\Phi}_{\boldsymbol{n}}$ is the $n$th mode shape and $q_{n}(t)$ is the modal co-ordinate which is governed by:

$\ddot{q}_{n}+2 \zeta_{n} \omega_{n} \dot{q}_{n}+\omega_{n}^{2} q_{n}=-\Gamma_{n} \ddot{u}_{g}(t)$

in which $\omega_{n}$ and $\zeta_{n}$ are the natural frequency and damping ratio of the $n$th mode, respectively. $\Gamma_{n}$ is the $n$th modal participating factor and is obtained as follows:

$\Gamma_{n}=\frac{\Phi_{n}^{T} \boldsymbol{m i}}{\Phi_{n}^{T} \boldsymbol{m} \Phi_{n}}$

The solution of Eq. (3) is given by:

$q_{n}(t)=\Gamma_{n} D_{n}(t)$

where $D_{n}(t)$ is governed by the equation of motion for a single-degree-of-freedom (SDOF) system with vibration properties of the $n$ th-mode of the MDOF system subjected to $\ddot{u}_{g}(t)$ :

$\ddot{D}_{n}+2 \zeta_{n} \omega_{n} \dot{D}_{n}+\omega_{n}^{2} D_{n}=-\ddot{u}_{g}(t)$

Substituting Eq. (5) into Eq. (2) gives the floor displacements: 
$\boldsymbol{u}(\boldsymbol{t})=\sum_{n=1}^{N} \Gamma_{n} \boldsymbol{\Phi}_{n} D_{n}(t)$

Eq. (7) gives the basis for the computation of lateral load distribution which is employed in the proposed displacement-based pushover procedure.

\subsection{Pushover lateral load distribution}

In order to incorporate the effect of higher modes into the NSP, some researchers have developed the enhanced multi-mode pushover methods (Chopra and Goel 2002; Chopra et al. 2004; Kalkan and Kunnath 2006) either in an adaptive or in a non-adaptive form assuming that the effects of different modes are uncoupled. These multi-mode pushover procedures are not able to consider the yielding effect of one mode on the other modes as well as the interaction between modes in the nonlinear range. On the other hand, several adaptive or non-adaptive single-run pushover procedures (Jan et al. 2004; kunnath 2004; Antoniou and Pinho 2004a; Antoniou and Pinho 2004b; Shakeri et al. 2010; Abbasnia et al. 2013; Poursha and Amini 2015) have been proposed to overcome the deficiency of conventional NSP in which structures are pushed with a single lateral load pattern. In these methods, the modal combination concept is employed to define the force-based or displacement-based lateral load distribution, instead of combining the seismic responses resulting from each mode.

In the force-based single-run pushover procedures, the modal story forces are combined using an appropriate modal combination rule to obtain a single lateral force distribution. Antoniou and Pinho (2004a) developed the FAP method in which the predictions of seismic responses were not significantly improved because of the use of the quadratic modal combination rules (i.e. SRSS and (QC). As mentioned before, the major drawback of these rules is that the effect of the sign inversion in the story forces of higher modes is not reflected in the applied load pattern. In order to remedy the deficiency of the FAP method through a force-based procedure, Shakeri et al. (2010) proposed a story shear-based adaptive pushover method where at each step the applied load pattern is derived from the modal story shears profile. Some other researchers (Kunnath 2004; Poursha and Amini 2015) proposed an invariant lateral force distribution for non-adaptive pushover analysis by algebraically adding or subtracting the modal story forces to consider the effect of the sign inversion in the load pattern.

On the other hand, however, in the displacement-based single-run pushover procedures, the modal story displacements are combined to obtain a single lateral displacement distribution. Antoniou and Pinho (2004b) proposed the DAP procedure which was the first-ever single-run pushover algorithm that was able to account for the effect of higher modes including the sign inversion in story forces. The only important difference between the DAP and FAP procedures stems from the use of the displacement loading rather than the force actions. In another investigation, Abbasnia et al. (2013) developed an adaptive displacement-based analysis in which a range of load patterns is computed by algebraically adding and subtracting of the modal load vectors. Therefore, multiple adaptive pushover analyses are required to be performed that are time-consuming and relatively complicated. This section presents an invariant lateral load distribution used in the proposed non-adaptive displacement-based pushover procedure.

Using Eq. (7), the maximum story displacements associated to each mode are computed by modal analysis as follows: 
$\boldsymbol{d}_{n}=\Gamma_{n} \boldsymbol{\Phi}_{n} S_{d_{n}}\left(\zeta_{n}, T_{n}\right)$

where $\boldsymbol{d}_{\boldsymbol{n}}$ is the lateral displacement distribution for the $n$th mode and $S_{d_{n}}$ is the spectral displacement as a function of vibration period, $T_{n}$, and damping ratio, $\zeta_{n}$, of the $n$th mode for a given earthquake ground motion. The modal lateral displacements are weighted by a weighting factor, $S_{d}$, to account for the effect of the frequency content of a particular input ground motion on the modal lateral load distribution. Previous studies (Antoniou and Pinho 2004a and b) demonstrated that the predictions of seismic responses are significantly improved when spectral amplification is incorporated into the lateral load distribution. As mentioned before, the DAP method employs the quadratic modal combination rules to combine the modal story displacements, whereas in the APAM procedure modal displacement vectors are algebraically added and subtracted to result in a range of load patterns. In this paper, however, an invariant lateral displacement distribution for pushover analysis is calculated by algebraically adding the modal story displacements. The following expression is, therefore, used to compute the story loads:

$\boldsymbol{D}_{k}=\sum_{i=1}^{k} \boldsymbol{d}_{i}=\sum_{i=1}^{k}\left|\Gamma_{i}\right| \boldsymbol{\Phi}_{i} S_{d i}\left(T_{i}, \zeta_{i}\right)$

where $\boldsymbol{D}_{\boldsymbol{k}}$ is the lateral displacement vector to be applied at the floor levels and $k$ is the number of vibration modes considered for the determination of the enhanced lateral displacement distribution. When using Eq. (9), the mode shapes are normalized so that the roof component of $\boldsymbol{\Phi}_{n}$ equals to unity. Therefore, in order to properly consider the contribution of each mode in the computation of lateral displacement distribution, the absolute value of modal participation factors should be employed in this equation. This causes the roof component of modal displacement vectors for all of the modes of interest to be in the same direction (see Figs. 1b and 1c). If the contributions of two or three modes of vibration are included in determining the applied load pattern, $D_{2}$ and $D_{3}$ can be computed as follows:

$\boldsymbol{D}_{2}=\boldsymbol{d}_{1}+\boldsymbol{d}_{2}=\left|\Gamma_{1}\right| \boldsymbol{\Phi}_{1} S_{d 1}\left(T_{1}, \zeta_{1}\right)+\left|\Gamma_{2}\right| \boldsymbol{\Phi}_{2} S_{d 2}\left(T_{2}, \zeta_{2}\right) \quad$ for two modes

$\boldsymbol{D}_{3}=\boldsymbol{d}_{1}+\boldsymbol{d}_{2}+\boldsymbol{d}_{3}=\left|\Gamma_{1}\right| \boldsymbol{\Phi}_{1} S_{d 1}\left(T_{1}, \zeta_{1}\right)+\left|\Gamma_{2}\right| \boldsymbol{\Phi}_{2} S_{d 2}\left(T_{2}, \zeta_{2}\right)+\left|\Gamma_{3}\right| \boldsymbol{\Phi}_{3} S_{d 3}\left(T_{3}, \zeta_{3}\right)$ for three modes

It is interesting to note that the effects of higher modes and frequency content of a particular response spectrum on the load pattern are simultaneously considered in the above-mentioned equations. The process of determining the applied load pattern in the non-adaptive displacementbased pushover analyses for a 15-story frame (described in Section 3) is schematically represented in Fig. 1. The specifications of the frame and the periods of the first three modes of vibration for linearly elastic vibration are listed in Table 1 . Also, the modal participation factors of the 15-story frame for the first three modes are $1.387,-0.595$, and 0.335 , respectively. First, an eigenvalue analysis should be performed to obtain the mode shapes of the structure (Fig. 1a). Then, the modal story displacements for each mode (Figs. $1 \mathrm{~b}$ and $1 \mathrm{c}$ ) are computed by using Eq. (8), and finally, the enhanced lateral load distribution which to be applied in the proposed pushover analysis method is calculated using Eq. (9) (Figs. 1b and 1c). 

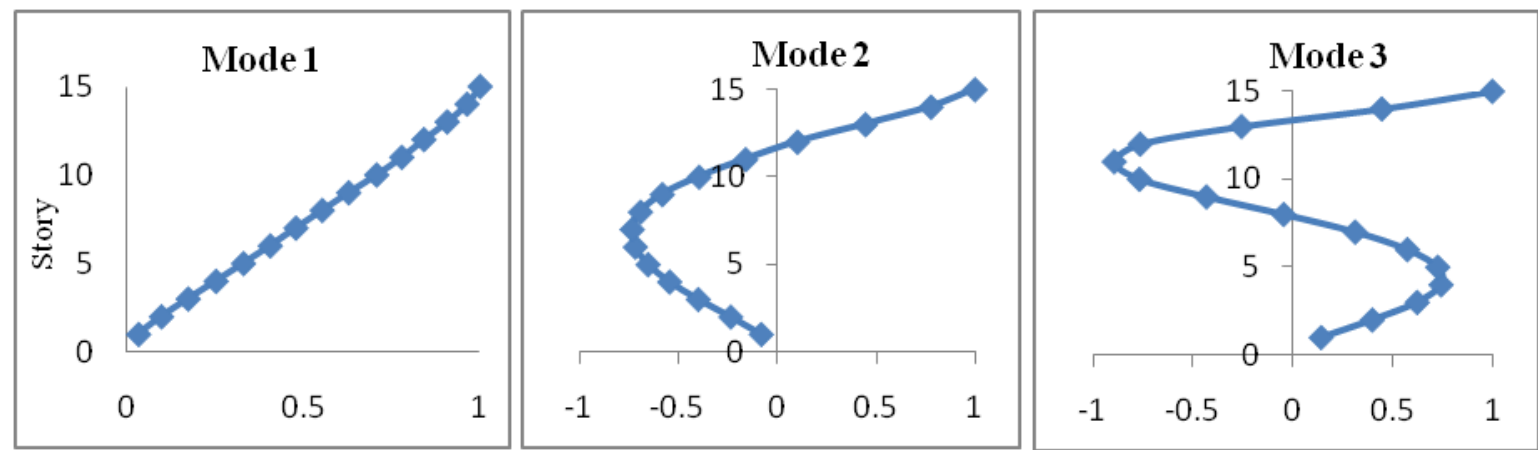

(a) The first three mode shapes of the structure
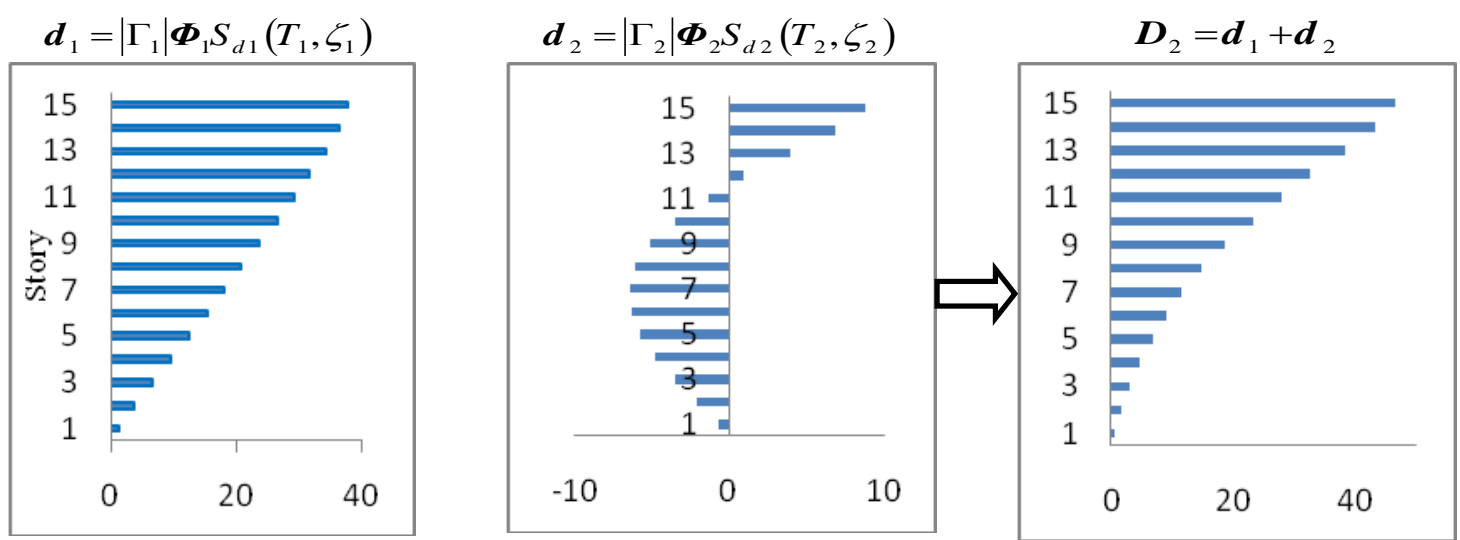

(b) Modal story displacements and lateral load distribution including the contributions of two modes
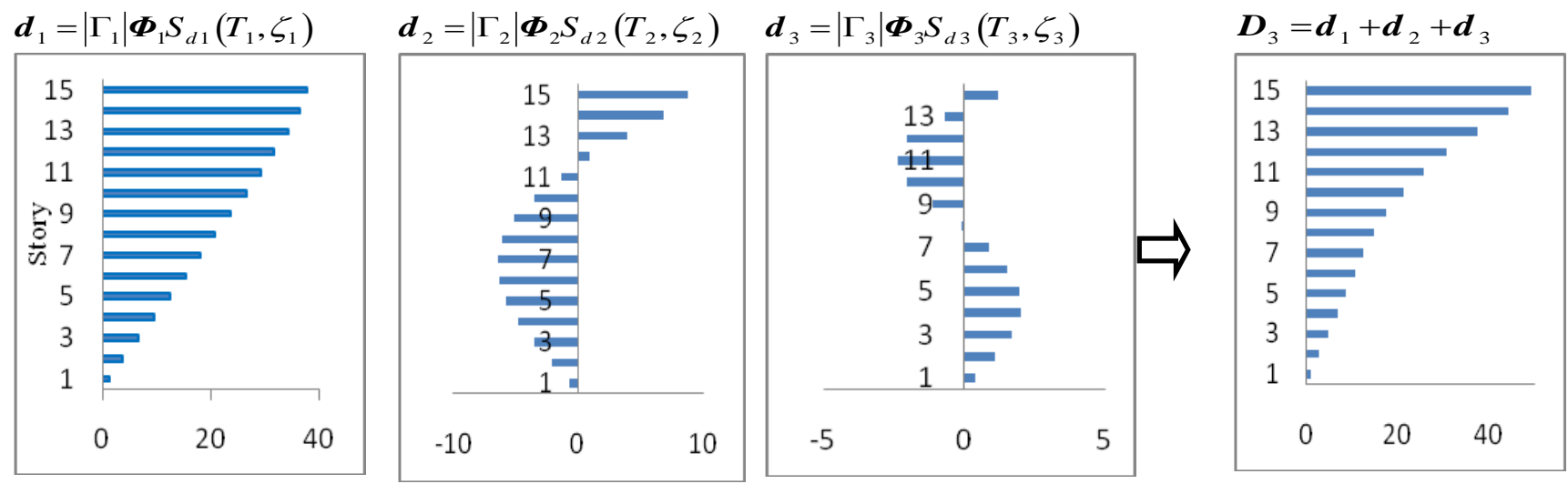

(c) Modal story displacements and lateral load distribution including the contributions of three modes

Fig. 1. The process of determining the applied lateral load distribution in the non-adaptive displacementbased pushover analyses

\subsection{A proposal for the computation of the target displacement}

Determination of the target displacement at which the seismic performance evaluation of the structure should be performed is a basic step in pushover analysis. The main assumption in conventional pushover analyses is that the target displacement for the MDOF system can be 
obtained from the displacement demand of the corresponding equivalent SDOF system. Inherent in this approach is the assumption that the target displacement is controlled by the fundamental mode of vibration without regarding the effect of higher modes. In this section, in order to account for the effect of the higher modes in estimating the target displacement for tall building structures, a simple method is proposed using the response spectrum analysis (RSA) procedure. While the mode shapes are normalized so that the roof component equals to unity, the peak roof displacement associated to each mode is computed using Eq. (8) as follows:

$\boldsymbol{d}_{r n}=\Gamma_{n} S_{d_{n}}\left(\zeta_{n}, T_{n}\right)$

It is worthwhile noting that, in the medium- and long-period ranges of response spectrum, the equal displacement rule applies, i.e., the displacement of an inelastic system is equal to the displacement of the corresponding elastic system with the same period (Fajfar 2000). It is also assumed that the structure remains in the elastic range when vibrating in higher modes (Kreslin and Fajfar 2011). Therefore, the value of $S_{d_{n}}$ for different modes in Eq. (12) can be estimated using the elastic response spectrum in the case of tall building frames. In order to determine the target displacement, the peak modal roof displacements for the first two or three modes are combined using the square root of sum of squares (SRSS) rule which provides appropriate results for structures with well separated natural frequencies.

\subsection{A non-adaptive displacement-based pushover analysis procedure}

In this section, a non-adaptive displacement-based pushover (NADP) procedure is demonstrated which can be used to estimate the peak seismic responses of inelastic structures subjected to earthquake excitations. Some single-run displacement-based pushover analyses are employed in the NADP procedure because it is possible to use different pushover analyses and to envelope the results (Fajfar 2000). First, a single-run displacement-based pushover analysis is performed by using a conventional lateral displacement distribution in accordance with the first mode shape. Also, one or two enhanced single-run displacement-based pushover analyses are carried out using the displacement distributions proposed in this paper (see Eq. (9)). The number of single-run pushover analyses using the enhanced displacement distributions described earlier, as well as the number of modes participating in the enhanced displacement distributions depends on the fundamental period, $T$, of the structure; the number of modes is limited to two or three modes. For structures with fundamental periods less than $2.2 \mathrm{~s}$, an enhanced single-run pushover analysis is performed with the lateral displacement distribution considering the first two modes (Eq. (10)). When the fundamental period of the structure is equal to or greater than $2.2 \mathrm{~s}$, two enhanced single-run pushover analyses are carried out using Eqs. (10) and (11) that account for the influence of two and three modes of the structure, respectively.

As mentioned above, a conventional single-run pushover analysis should be performed using the displacement distribution according to the first mode shape in all cases. Finally, the seismic demands of the structure are obtained by enveloping the peak seismic responses derived from the conventional single-run and enhanced single-run pushover analyses. In order to compute the enhanced displacement distributions with the aid of Eq. (9), an eigenvalue analysis of the linearly elastic structure should be implemented. Changes in the modal properties of the structure are ignored when the structure experiences the nonlinear deformations under increasing lateral loads. It should be noted that the limit period of $2.2 \mathrm{~s}$ was considered according to the investigation in 
Reference (Poursha et al. 2009) for steel moment-resisting frames. This limit value is almost close to the limit period of $\mathrm{T}=2.5 \mathrm{~s}$ which has been specified in the equivalent lateral force (ELF) distribution in FEMA-356 (FEMA 2000). For all the single-run pushover analyses, the target displacement can be determined by using the proposed method in this paper (see section 2.3), or the nonlinear dynamic analysis of the structure (Tso and Moghadam 1998; Mwafy and Elnashai 2001; Kreslin and Fajfar 2011).

The NADP procedure can be summarized in a sequence of the following steps:

1. Develop an appropriate structural model incorporating the nonlinear material characteristics.

2. Perform an eigenvalue analysis to calculate the natural frequencies, $\omega_{n}$, and mode shapes, $\boldsymbol{\Phi}_{n}$, of the first three modes for linearly elastic vibration of the structure. Also, normalize mode shapes such that the roof component of $\boldsymbol{\Phi}_{n}$ equals to unity.

3. Obtain the enhanced lateral load distributions by using Eqs. (10) and (11) accounting for the two and three modal story displacements, respectively.

4. Compute the target displacement of the structure at the roof level.

5. The NADP procedure consists of some (two or three) single-run displacement-based pushover analyses. First, apply the gravity loads and then carry out the single-run pushover analyses in accordance with the following sub-steps:

5.1. Perform the first single-run displacement-based pushover analysis using a load pattern according to the first mode shape, until the roof displacement sways to the predefined target displacement.

5.2. The second single-run pushover analysis is carried out using the enhanced lateral displacement distribution, which is obtained using Eq. (10) including the contributions of two modes, until the roof displacement reaches the target displacement.

5.3. The third single-run pushover analysis is only performed for buildings having a fundamental period of $2.2 \mathrm{~s}$ or more. In this analysis, the enhanced lateral load distribution calculated by Eq. (11) is applied to the structure until the roof displacement sways to the predetermined target displacement.

6. Calculate the desired seismic responses such as, displacements, story drift ratios, and plastic hinge rotations, for the single-run pushover analyses described above. The peak values resulting from the single-run pushover analyses in sub-steps 5.1, 5.2, and 5.3 are denoted by $r_{1}, r_{2}$, and $r_{3}$, respectively.

7. Compute the seismic demands of the inelastic structure for the NADP procedure by enveloping the peak seismic responses resulting from the single-run pushover analyses. Therefore, the envelope, $r$, of the peak seismic responses is derived as follows:

$$
\begin{aligned}
& r=\operatorname{Max}\left\{r_{1}, r_{2}\right\} \\
& r=\operatorname{Max}\left\{r_{1}, r_{2}, r_{3}\right\}
\end{aligned}
$$

\section{Validation of the proposed procedure}

In order to evaluate the accuracy of the proposed procedure in estimating the seismic demands of tall buildings, three special steel moment-resisting frames (MRFs) with different heights were selected from Reference (Poursha et al. 2009). Also, a 9-story steel moment-resisting building frame as part of the SAC Phase II Steel Project was used. Story drift ratios and plastic hinge 
rotations were computed to verify the proposed procedure. The seismic demands of the structures computed by the NADP procedure were compared to those from the nonlinear response history analysis (NL-RHA) as the most accurate method of seismic demand evaluation. The NL-RHA was implemented using a set of twenty ground motion records. Moreover, the seismic demands resulting from the DAP and MPA methods, as well-known displacement- and force-based pushover analysis methods, respectively, as well as from a conventional pushover procedure are presented for the sake of comparison.

\subsection{Numerical models}

In this paper, the 10-, 15-, and 20-story structures were three-bay frames with three different heights, covering a wide range of fundamental periods. These frames consisted of three 5m-bays. All stories were $3.2 \mathrm{~m}$ high throughout. The configuration of the frames is shown in Fig. 2 . The specifications of the frames and the periods of the first three modes for linearly elastic vibration are listed in Table 1. More details of the structural models can be found in References (Poursha et al. 2009, 2010). In addition to these three structures, a 9-story steel moment-resisting frame as part of the SAC Phase II Steel Project denoted as SAC9 was considered. As shown in Fig. 3, the moment-resisting frame in the north-south $(\mathrm{N}-\mathrm{S})$ direction of the building was used in the current investigation. The periods of the first three modes for linearly elastic vibration of the SAC9 frame are 2.368, 0.887, and $0.510 \mathrm{~s}$, respectively. More details of the SAC-Los Angeles 9story building can be found in Reference (Kim and Kurama 2008).

All the nonlinear analyses were performed using the OpenSees (2014) program. Geometrical nonlinearity and material inelasticity were taken into account in all the models. The material inelasticity was explicitly considered by employing a fiber modeling approach. The column and beam members were modeled using a force-Beam-Column element that uses distributed plasticity within a specified length of the member ends. In this paper, the plastic hinge length was assumed to be equal to the section height.

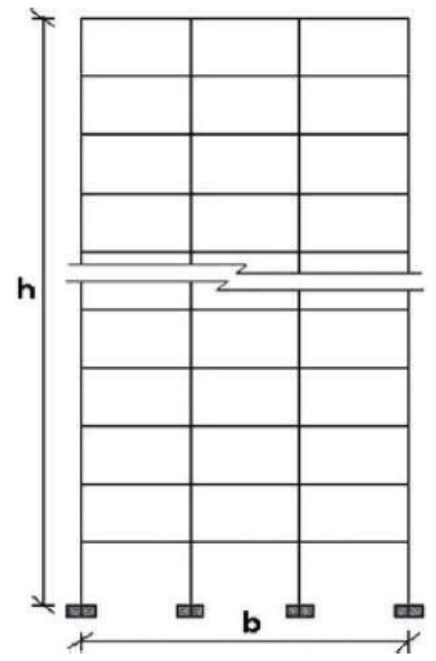

Fig. 2. Configuration of the 2-dimensional frames (Poursha et al. 2009) 
Table 1. Characteristics of the analyzed frames with different heights (Poursha et al. 2009)

\begin{tabular}{llllclll}
\hline \multirow{2}{*}{ No. } & No. of stories & $\mathrm{h}(\mathrm{m})$ & $\mathrm{b}(\mathrm{m})$ & Seismic mass of floors $\left(\mathrm{kg} \mathrm{s}^{2} / \mathrm{m}\right)$ & \multicolumn{3}{c}{ Periods } \\
\cline { 6 - 8 } & & & & & $\mathrm{T}_{1}(\mathrm{~s})$ & $\mathrm{T}_{2}(\mathrm{~s})$ & $\mathrm{T}_{3}(\mathrm{~s})$ \\
\hline $\mathrm{S} 1$ & 10 & 32 & 15 & 5440 & 1.692 & 0.604 & 0.346 \\
$\mathrm{~S} 2$ & 15 & 48 & 15 & 5546 & 2.331 & 0.852 & 0.492 \\
$\mathrm{~S} 3$ & 20 & 64 & 15 & 5600 & 3.058 & 1.125 & 0.667 \\
\hline
\end{tabular}

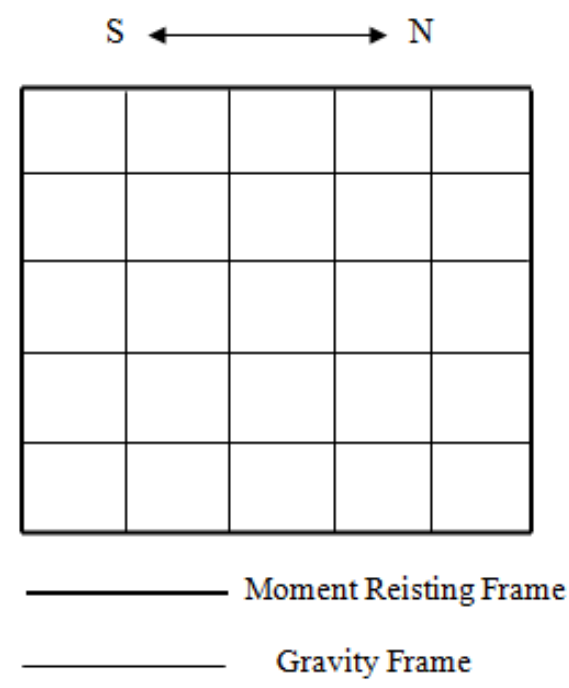

(a) Plan view

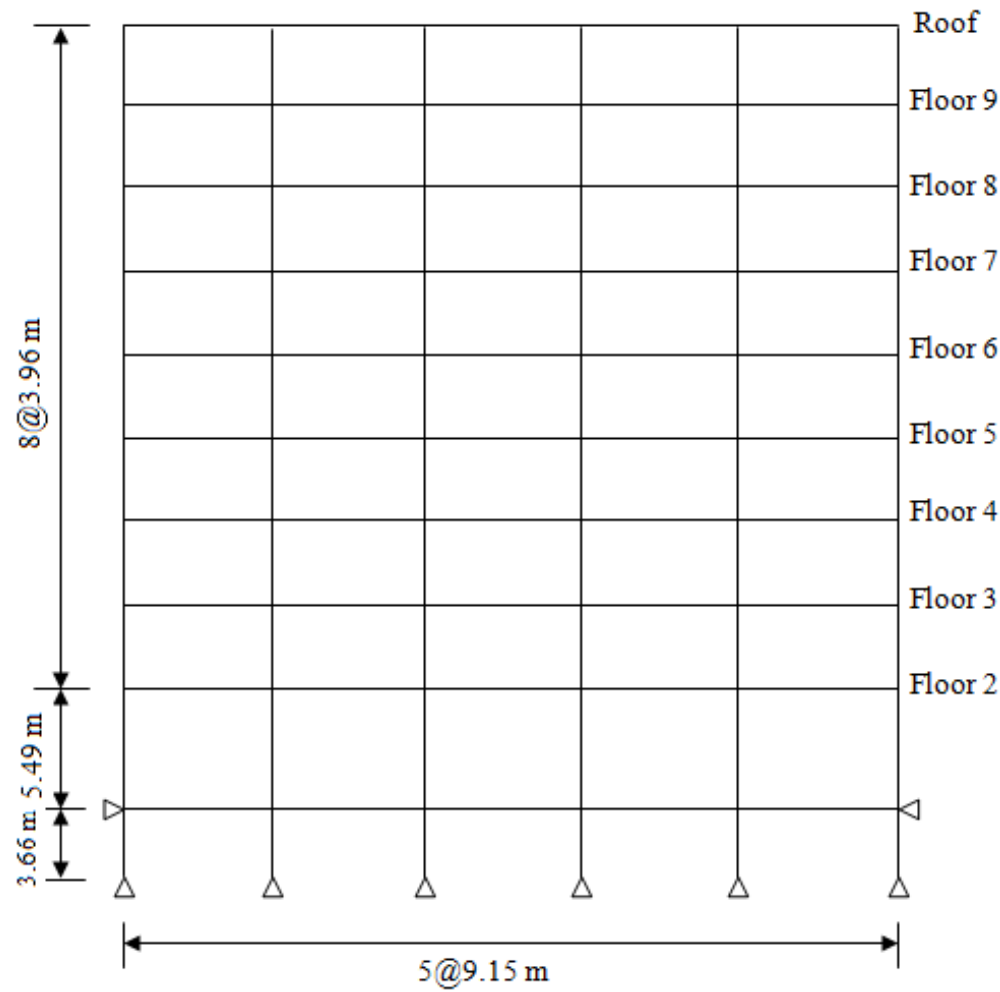

(b) N-S moment-resisting frame elevation

Fig. 3. Configuration of the 9-story SAC frame (Kim and Kurama 2008)

\subsection{Ground motions}

To evaluate the NADP procedure, the nonlinear response history analyses were performed. In order to develop a reliable set of benchmark responses, for 10-, 15-, and 20-story frames, twenty ground motion records from thirteen different earthquakes were selected from the strong ground motion database of the Pacific Earthquake Engineering Research (PEER) Center (http://peer.berkeley.edu). The selected ground motions were far-field records, and corresponded to locations which were at least $12 \mathrm{~km}$ from a fault. Furthermore, the soil at the site corresponds to NEHRP site class $\mathrm{C}$. To ensure that the seismic ground motions drive the building frames well into the inelastic range, the records were scaled up to $0.7 \mathrm{~g}$. More characteristics of the records are given in Table 2. The elastic displacement spectra, as well as the mean spectrum, for a damping ratio of 5\% are presented in Fig. 4 . The mean spectrum is shown by a thicker line.

For the 9-story SAC building frame, a total of 20 far fault ground motion records (LA01LA20) were used to evaluate the proposed pushover procedure. These design-level ground 
motions which correspond to a $10 \%$ probability of exceedance in 50 years were compiled by the SAC Phase II Steel Project for a site in Los Angeles with a stiff soil profile (Site Class D in the IBC-2003). More characteristics of these ground motions are given in Table 3. For each ground motion, a single scaling factor was obtained. The ground motions were scaled based on the minimizing of the weighted sum of the squared differences between the average 5\%-damped linear-elastic acceleration response spectra of the two horizontal components and the corresponding target response spectrum in the period range of 0.3-4 s (Kim and Kurama 2008). More details about the scaling of the ground motions can be found in the mentioned reference.

Table 2. List of the ground motions used for the 10-, 15-, and 20-story frames.

\begin{tabular}{|c|c|c|c|c|c|c|c|c|c|}
\hline No. & Earthquake & Date & Station & Magnitude & Component & $\begin{array}{c}\text { Fault } \\
\text { Distance }(\mathrm{km}) \\
\end{array}$ & $\operatorname{PGA}(\mathrm{g})$ & $\mathrm{PGV}(\mathrm{cm} / \mathrm{s})$ & PGD $(\mathrm{cm})$ \\
\hline 1 & Duzce, Turkey & $11 / 12 / 1999$ & Lamont 1061 & 7.1 & $\mathrm{E}$ & 15.60 & 0.13 & 13.69 & 8.20 \\
\hline 2 & Hollister & $1 / 26 / 1986$ & SAGO South - surface & $\operatorname{Ml}(5.5)$ & 295 & - & 0.09 & 9.27 & 1.70 \\
\hline 3 & Imperial Valley & $10 / 15 / 1979$ & Parachute Test Site & 6.5 & 315 & 14.20 & 0.20 & 16.06 & 9.97 \\
\hline 4 & Imperial Valley & $10 / 15 / 1979$ & Cerro Prieto & 6.5 & 147 & 26.50 & 0.17 & 11.58 & 4.24 \\
\hline 5 & Imperial Valley & $10 / 15 / 1979$ & Superstition Mtn Camera & 6.5 & 135 & 26.00 & 0.20 & 8.78 & 2.78 \\
\hline 6 & Kern County & $7 / 21 / 1952$ & Taft Lincoln School & 7.4 & 111 & 41.00 & 0.18 & 17.48 & 8.84 \\
\hline 7 & Livermore & $1 / 24 / 1980$ & CSUH & 5.8 & 146 & 31.00 & 0.07 & 4.11 & 0.75 \\
\hline 8 & Loma Prieta & $10 / 18 / 1989$ & Anderson Dam & 6.9 & 250 & 21.40 & 0.24 & 20.28 & 7.69 \\
\hline 9 & Loma Prieta & $10 / 18 / 1989$ & Coyote Lake Dam & 6.9 & 285 & 22.30 & 0.18 & 22.63 & 13.18 \\
\hline 10 & Loma Prieta & $10 / 18 / 1989$ & Hayward- BART Sta & 6.9 & 220 & 58.90 & 0.16 & 15.06 & 3.74 \\
\hline 11 & Morgan Hill & $4 / 24 / 1984$ & Corralitos & 6.2 & 310 & 22.7 & 0.109 & 10.788 & 2.133 \\
\hline 12 & N. Palm Springs & 7/8/1986 & Cranston Forest Station & 6 & 315 & 35.30 & 0.17 & 11.70 & 1.15 \\
\hline 13 & Northridge & $1 / 17 / 1994$ & Featherly Park & 6.7 & 0 & 84.20 & 0.10 & 7.64 & 0.81 \\
\hline 14 & Northridge & $1 / 17 / 1994$ & LA- Baldwin Hills & 6.7 & 90 & 31.70 & 0.24 & 14.85 & 6.22 \\
\hline 15 & Northridge & $1 / 17 / 1994$ & Inglewood-Union Oil & 6.7 & 90 & 44.70 & 0.10 & 10.25 & 3.21 \\
\hline 16 & Northridge & $1 / 17 / 1994$ & LA-Chalon Rd & 6.7 & 70 & 23.70 & 0.23 & 16.59 & 3.39 \\
\hline 17 & San Fernando & 2/9/1971 & Palmdale Fire Station & 6.6 & 210 & 25.40 & 0.15 & 8.09 & 1.87 \\
\hline 18 & Trinidad, California & $11 / 8 / 1980$ & Rio Dell Overpass FF & $\operatorname{Ms}(7.2)$ & 270 & - & 0.15 & 8.48 & 3.25 \\
\hline 19 & Victoria, Mexico & $6 / 9 / 1980$ & Cerro Prieto & $\operatorname{Ms}(6.4)$ & 45 & - & 0.62 & 31.58 & 13.08 \\
\hline 20 & Westmorland & $4 / 26 / 1981$ & Parachute Test Site & 5.8 & 225 & - & 0.24 & 39.23 & 26.89 \\
\hline
\end{tabular}

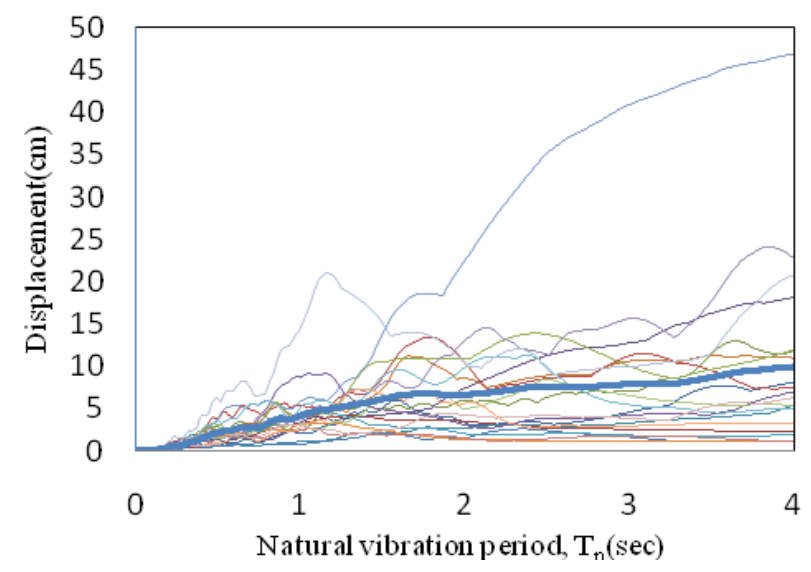

Fig. 4. Displacement spectra of the ground motions used for the 10-, 15-, and 20-story frames for a damping ratio of $5 \%$. 


\subsection{Description of analyses}

The structural models of the frames S1, S2, and S3 (see Table 1) were subjected to the scaled strong ground motions listed in Table 2. Also, the SAC LA01-LA20 ground motion records were used for the 9-story SAC frame. The results of NL-RHA were calculated as the mean values of the maximum seismic demands obtained by nonlinear response history analyses for each frame. The seismic demands resulting from different pushover analysis procedures are compared to those from NL-RHA. The proposed NADP procedure was performed as elaborated in detail earlier. Also, the MPA and DAP procedures, as well-known force- and displacement-based pushover procedures, respectively, were implemented for the purpose of comparison. Moreover, a conventional force-based pushover analysis with the first mode shape prescribed in ASCE-41 (2006) was carried out. The seismic responses for the MPA procedure were computed by including the contributions of three modes in the case of the 9-story SAC, 10- and 15-story frames, and by including the contributions of five modes of vibration in the case of the 20-story frame. The last version of the MPA procedure (Reyes and Chopra 2011) was employed to predict plastic hinge rotations, because the original procedure fails to accurately estimate plastic rotations for tall building frames (Chopra and Goel 2004; Poursha et al. 2009). To this end, after applying the gravity loads, a set of displacements that are compatible with the computed story drifts were imposed at the story levels.

Table 3. List of the design basis earthquake (DBE) ground motions used for the 9-story SAC frame.

\begin{tabular}{clcccc}
\hline Record Name & \multicolumn{1}{c}{ Site Location } & Magnitude & Distance $(\mathrm{km})$ & Scale Factor & PGA $(\mathrm{g})$ \\
\hline LA01 & Imperial Valley, 1940, El Centro & 6.9 & 10 & 2.01 & 0.46 \\
LA02 & Imperial Valley, 1940, El Centro & 6.9 & 10 & 2.01 & 0.68 \\
LA03 & Imperial Valley, 1979, Array \#05 & 6.5 & 4.1 & 1.01 & 0.39 \\
LA04 & Imperial Valley, 1979, Array \#05 & 6.5 & 4.1 & 1.01 & 0.49 \\
LA05 & Imperial Valley, 1979, Array \#06 & 6.5 & 1.2 & 0.84 & 0.30 \\
LA06 & Imperial Valley, 1979, Array \#06 & 6.5 & 1.2 & 0.84 & 0.23 \\
LA07 & Landers, 1992, Barstow & 7.3 & 36 & 3.20 & 0.42 \\
LA08 & Landers, 1992, Barstow & 7.3 & 36 & 3.20 & 0.42 \\
LA09 & Landers, 1992, Yermo & 7.3 & 25 & 2.17 & 0.52 \\
LA10 & Landers, 1992, Yermo & 7.3 & 25 & 2.17 & 0.36 \\
LA11 & Loma Prieta, 1989, Gilroy & 7.0 & 12 & 1.79 & 0.66 \\
LA12 & Loma Prieta, 1989, Gilroy & 7.0 & 12 & 1.79 & 0.97 \\
LA13 & Northridge, 1994, Newhall & 6.7 & 6.7 & 1.03 & 0.68 \\
LA14 & Northridge, 1994, Newhall & 6.7 & 6.7 & 1.03 & 0.66 \\
LA15 & Northridge, 1994, Rinaldi RS & 6.7 & 7.5 & 0.79 & 0.53 \\
LA16 & Northridge, 1994, Rinaldi RS & 6.7 & 7.5 & 0.79 & 0.58 \\
LA17 & Northridge, 1994, Sylmar & 6.7 & 6.4 & 0.99 & 0.57 \\
LA18 & Northridge, 1994, Sylmar & 6.7 & 6.4 & 0.99 & 0.82 \\
LA19 & North Palm Springs, 1986 & 6.0 & 6.7 & 2.97 & 1.02 \\
LA20 & North Palm Springs, 1986 & 6.0 & 6.7 & 2.97 & 0.99 \\
\hline
\end{tabular}

At each step of the DAP procedure, an eigenvalue analysis was carried out to determine the required modal parameters for the computation of the displacement load pattern. The story driftbased scaling technique was employed for the DAP in this paper, because it was shown that using modal story drifts, rather than the modal story displacements, results in a more realistic estimation of seismic demands especially for story drift profiles (Antoniou and Pinho 2004b). 
Updating the loading vector in the DAP procedure was performed by using the incremental updating method due to its numerical stability and more adequate results (Antoniou and Pinho 2004b). In this study, in order to verify the proposed lateral load distribution, the target displacement at the roof for the NADP, DAP and conventional pushover procedures was assumed equal to the mean value of the maximum top floor displacements resulting from the NL-RHAs for the selected ground motions. The target displacements were equal to 49.55, 28.63, 33.58 , and $38.40 \mathrm{~cm}$ for the frames SAC9, S1, S2, and S3, respectively. Furthermore, to evaluate the proposed method for the determination of the target displacement, an additional study was carried out that the relevant results are reported at the end of this paper.

A step by step numerical integration based on the Newmark's constant average acceleration method (Chopra 2001) was employed to carry out the nonlinear response history analyses (NLRHAs). The damping matrix was defined using the Rayleigh damping (Chopra 2001) with a damping ratio of $5 \%$ for the first and third modes of vibration for the 10-, 15-, and 20-story frames, and a damping ratio of $3 \%$ for periods of $T_{1}$ and $0.1 T_{1}$ for the SAC frame.

\section{Description and discussion of the results}

As described previously, the NADP procedure uses some single-run conventional and enhanced displacement-based pushover analyses. The seismic responses are then estimated by enveloping the peak responses from these pushover analyses. The results provide evidence that the single-run conventional and enhanced pushover analyses control the seismic demands at the lower and upper stories, respectively. Fig. 5 shows the peak values of story drift ratios for the 15story frame derived from the single-run conventional and enhanced pushover analyses and also from the NL-RHA. As can be seen in the figure, the story drift ratios resulting from the singlerun conventional pushover analysis are close to those of the NL-RHA at the eight lower stories, whereas the single-run enhanced pushover analyses considering the first two and three modes govern the responses at the subsequent three and four stories, respectively. As a result, accounting for the contributions of higher modes in the enhanced lateral load distributions strongly affects the responses at the mid and upper stories, contrary to the lower stories. A similar conclusion can be drawn for plastic hinge rotations that are studied in this study.

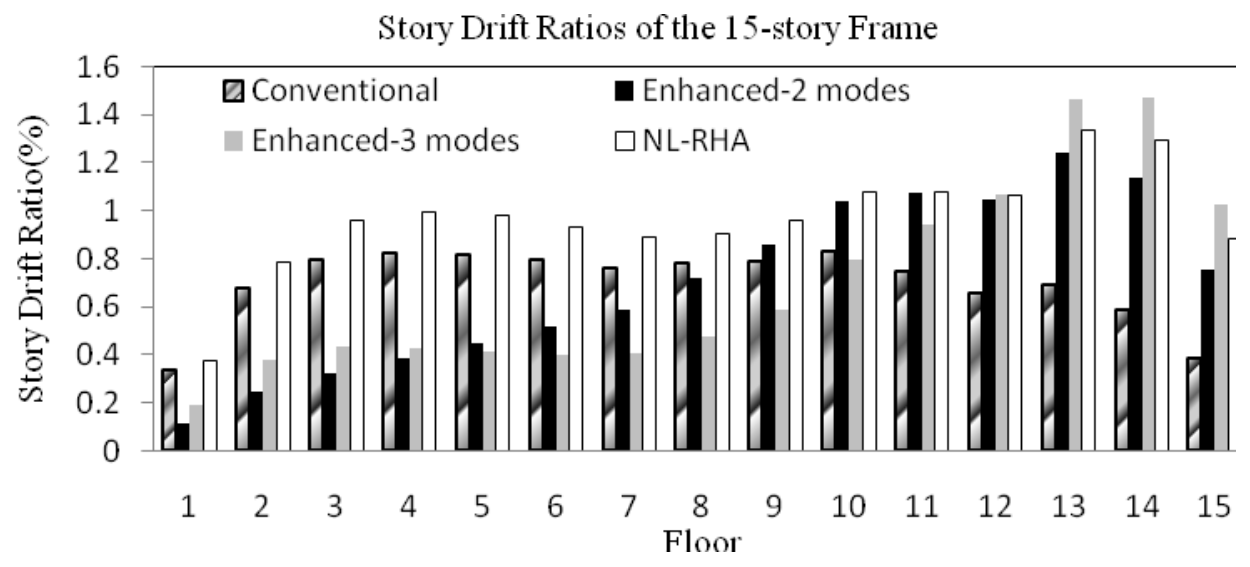

Fig. 5. Story drift ratios derived from the single-run displacement-based pushover analyses used in the NADP procedure and from the NL-RHA 
The story drift ratios resulting from the MPA, DAP, NADP, and conventional pushover procedures, together with the NL-RHA, for the frames SAC9, S1, S2 and S3 are displayed in Fig. 6. As expected, the conventional force-based pushover analysis with the first mode shape is unable to predict the story drifts at the upper stories with acceptable accuracy. Although the height-wise distribution of story drifts derived from the DAP procedure is similar to that of the NL-RHA, this procedure underestimates the story drifts in all of the stories. As can be seen in the figure, the MPA and NADP procedures predict the story drifts with sufficient accuracy. The MPA procedure provides better estimates of story drifts than the NADP at the lower stories, while the story drifts obtained from the NADP are better than those from the MPA at the upper stories.

In order to accurately compare the results derived from different pushover procedures, it would be better to study the errors for the lower and upper stories, separately. Herein, an error index (Lopez-Menjivar and Pinho 2004, Shakeri et al. 2010) defined by Eq. (15) is employed to measure the accuracy of different methods in estimating the story drifts at the lower and upper stories:

$$
\operatorname{Error}(\%)=100 * \frac{1}{n} \sqrt{\sum_{i=1}^{n}\left(\frac{\Delta_{i-N L R H A}-\Delta_{i-N S P}}{\Delta_{i-N L R H A}}\right)^{2}}
$$

where, $\Delta_{i-N L R H A}$ and $\Delta_{i-N S P}$ are the story drift ratios at a given level $i$, resulting from the NLRHA and pushover analyses, respectively, and $n$ is the number of the stories. The error indices for different pushover procedures in estimating the story drifts at the lower and upper stories of the SAC9, 10-, 15-, and 20-story frames are shown in Fig. 7a and 7b, respectively. The five, five, eight, and ten lower stories were considered as the lower stories for the SAC9, 10-, 15-, and 20story frames, respectively. The figures indicate that the errors in the DAP procedure are larger than those in the MPA and NADP procedures for all cases, except at the lower stories of the SAC9 frame. Furthermore, as shown in Fig. 7a, the errors in the MPA procedure at the lower stories of all the frames are less than those in the NADP, whereas the errors in the NADP at the upper stories are less than those in the MPA (see Fig. 7b). The results confirm that the use of the SRSS rule for combining the modal story displacements in the DAP procedure, incorporating the higher modes effect into a single-run displacement-based pushover analysis, does not lead to accurate estimations of the seismic responses because the signs of modal displacement vectors are suppressed in the combination process. Instead, applying the algebraic sum rule for combining the modal story displacements can lead to accurate predictions of the seismic demands at the upper stories of tall buildings in which the effect of higher modes is significant. In this manner, the sign of each modal displacement vector is preserved and the sign reversal in the lateral displacement distributions can be included.

Fig. 6 shows that the NADP procedure underestimates the story drifts at the lower stories. As mentioned previously, the single-run conventional pushover analysis with the first mode shape controls the seismic demands at the lower stories. In this conventional pushover procedure, most of the plastic deformations of the structures occur at the lower stories. However, because of the non-adaptive nature of this analysis, changes in the first mode shape are not considered in the lateral load distribution. 


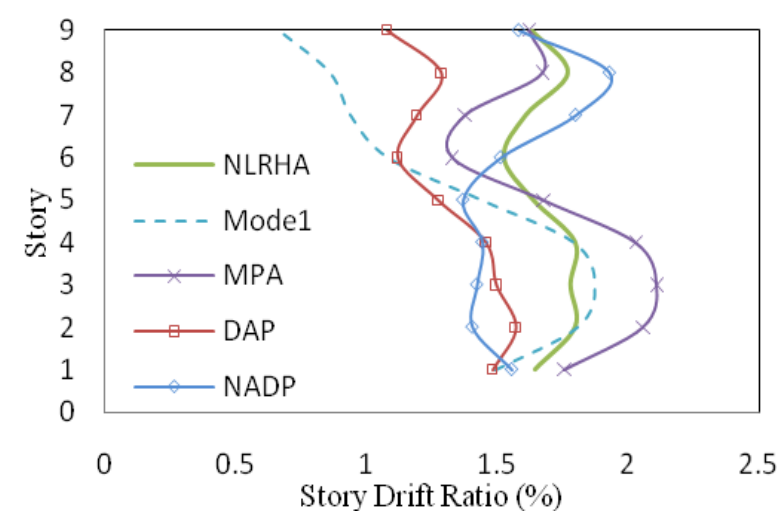

(a) 9-story SAC frame

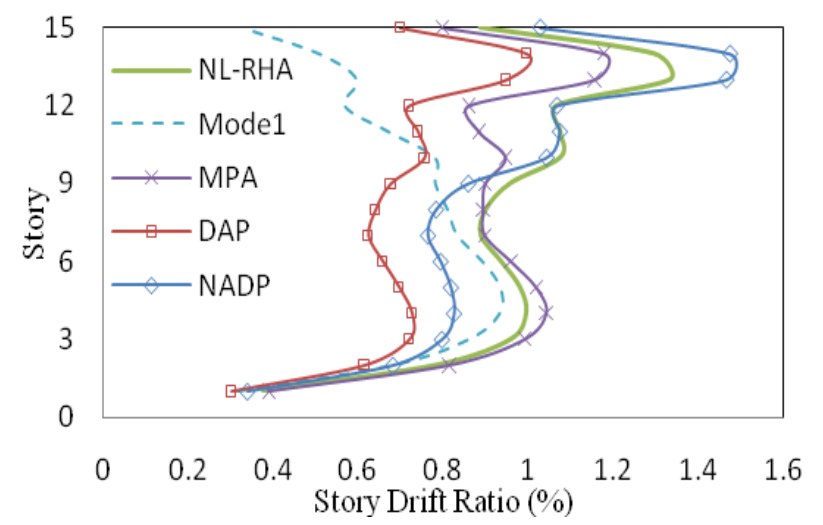

(c) 15-story frame

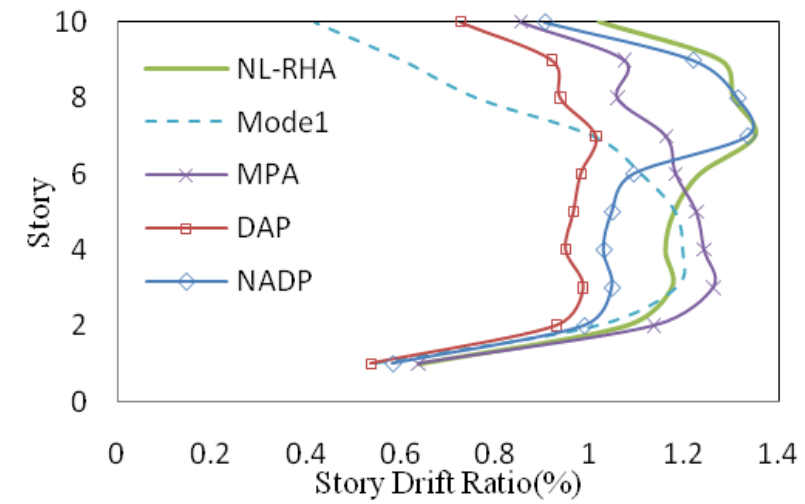

(b) 10-story frame

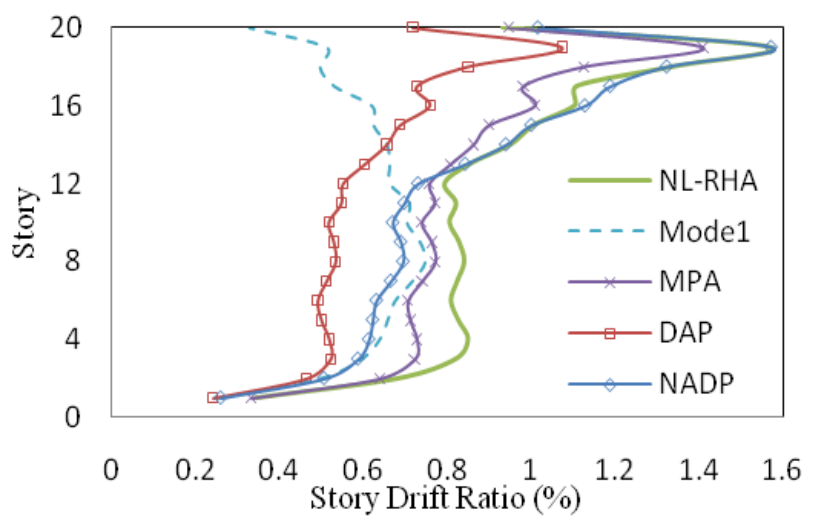

(d) 20-story frame

Fig. 6. Height-wise variation of the story drifts

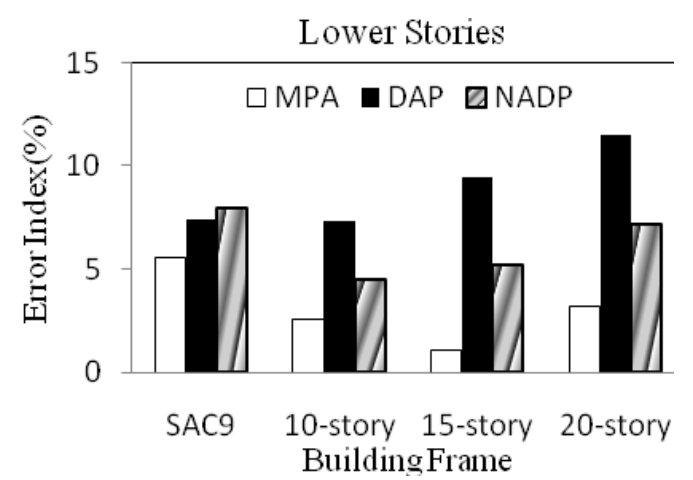

(a) Error indices at the lower stories

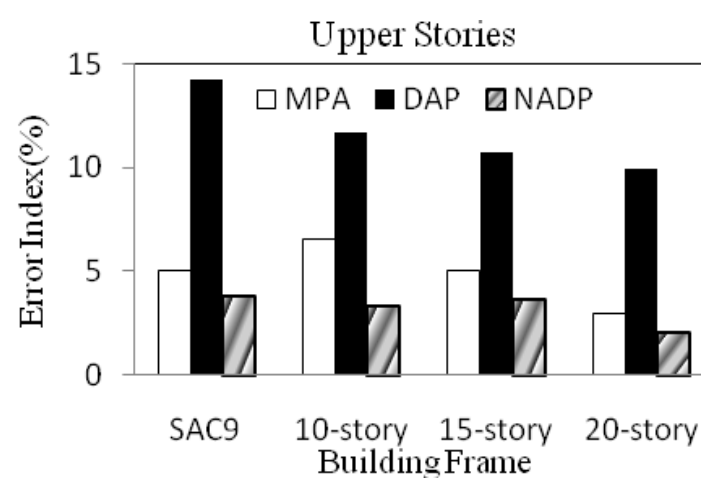

(b) Error indices at the upper stories

Fig. 7. Error indices in the story drifts at the lower and upper stories of the frames

Fig. 8 shows the height-wise variation of plastic hinge rotations for the beam in the middle span of the building frames. As previously mentioned, the last version of the MPA procedure (Reyes and Chopra 2011) was employed to predict plastic hinge rotations from the story drifts. The figure illustrates that the DAP procedure significantly underestimates the plastic hinge rotations at all stories of the frames. As can be seen in the figure, the MPA procedure is in better agreement with the NL-RHA than the NADP at the lower floors, while the plastic hinge rotations obtained by the NADP are more accurate than those computed by the MPA at the upper floors where the effect of higher modes is substantially important. Fig. 9 shows the error indices for 


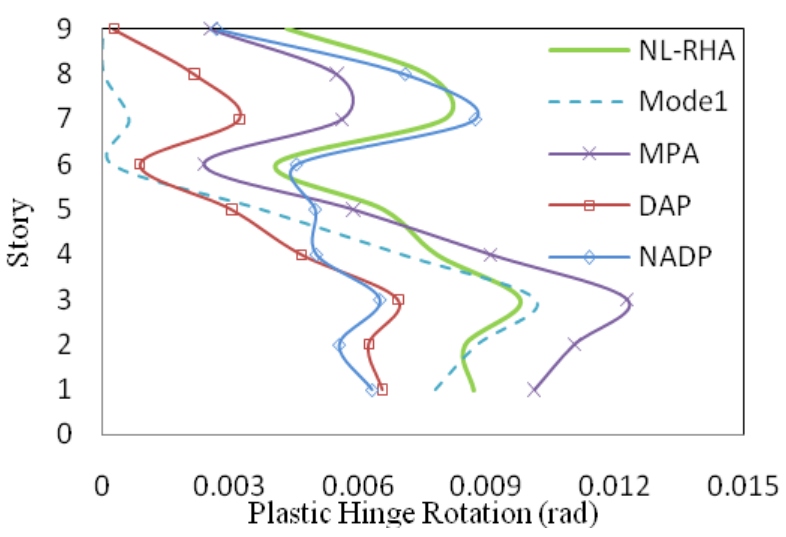

(a) 9-story SAC frame

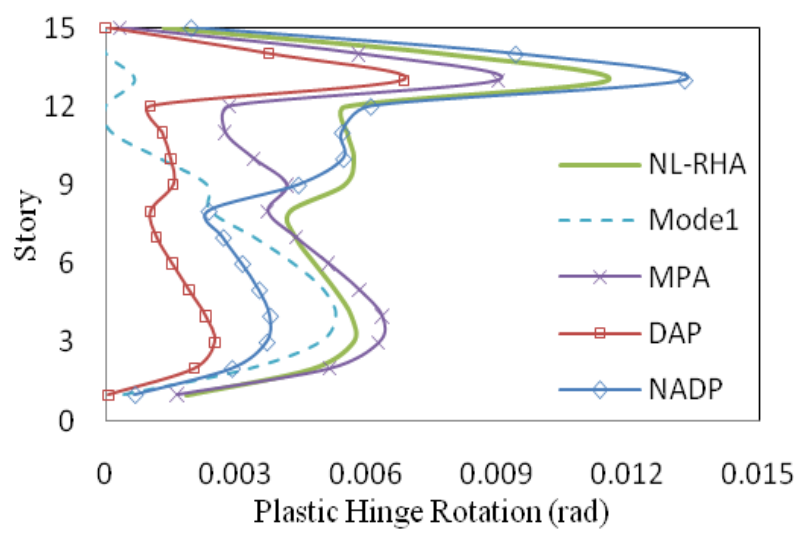

(c) 15-story frame

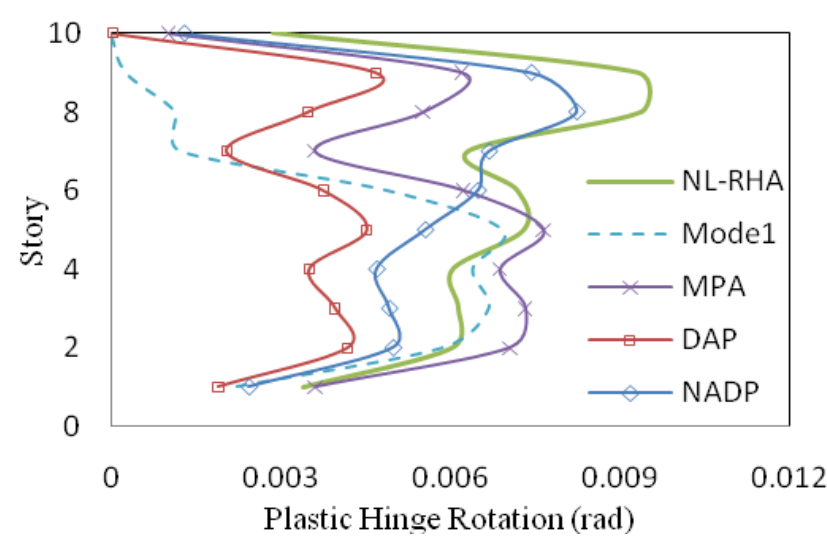

(b) 10-story frame

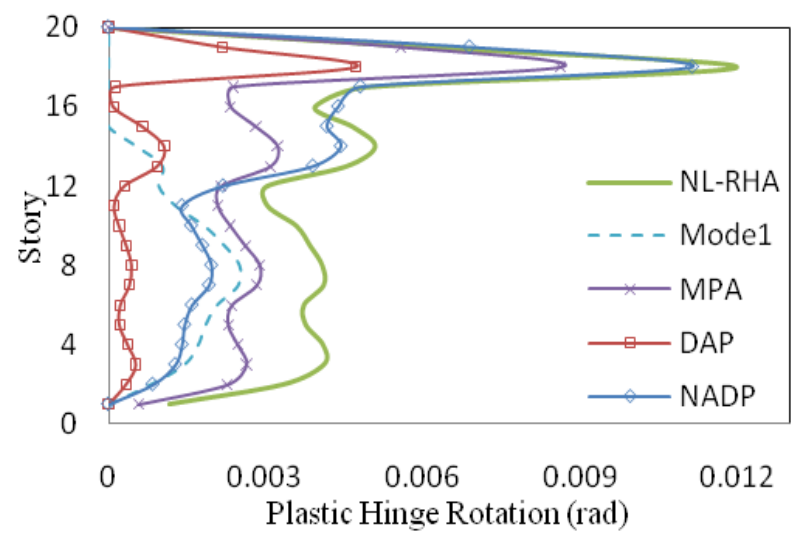

(d) 20-story frame

Fig. 8. Height-wise variation of the plastic hinge rotations

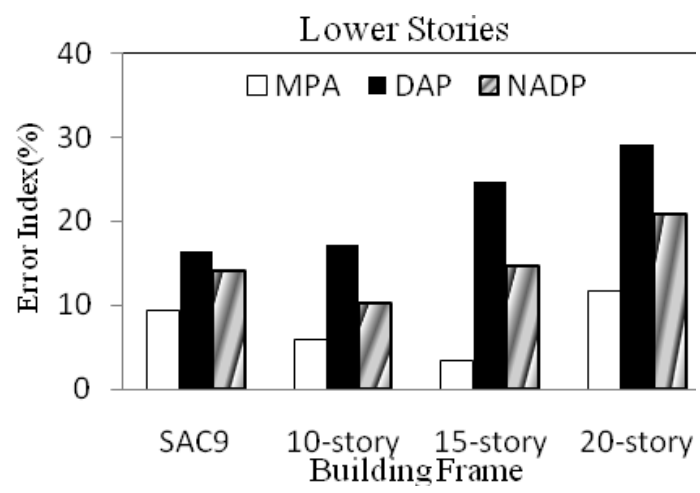

(a) Error indices at the lower stories

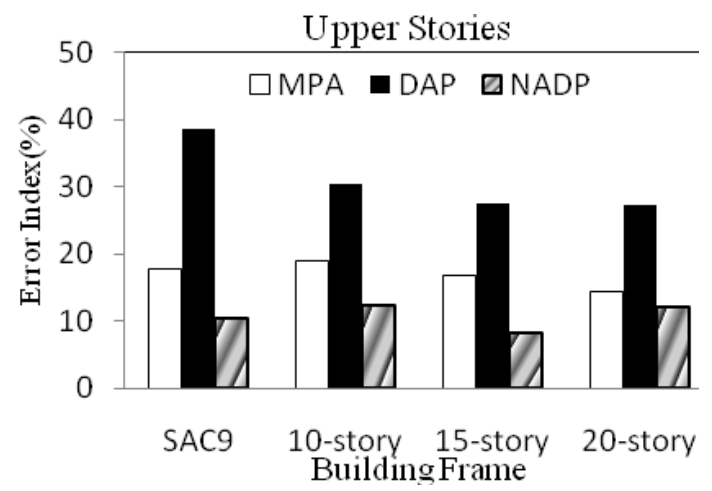

(b) Error indices at the upper stories

Fig. 9. Error indices in the plastic hinge rotations at the lower and upper stories of the frames

different pushover procedures in estimating plastic hinge rotations at the lower and upper stories of the SAC9, 10-, 15-, and 20-story frames. The less accuracy of the MPA procedure in estimating the plastic hinge rotations at the upper stories in comparison with the NADP method is due to the fact that the MPA procedure attempts to predict the overall response quantities by combining the individual peak responses obtained separately for each mode of vibration. Figs. 6 to 9 demonstrate that the employment of an invariant lateral load distribution in a single-run 
pushover procedure, which was obtained by combining the modal story displacements with the aid of an appropriate modal combination rule, can be more efficient than the use of a multi-run pushover procedure in taking into account the higher modes effect, particularly at the upper stories. Moreover, because the NADP is a non-adaptive pushover procedure, contrary to the DAP, it is not complicated in the practical implementation and does not require more computational effort and time cost. Fig. 10 shows the time elapsed in performing the DAP and NADP procedures for the SAC9, 10-, 15-, and 20-story frames. The figure illustrates that the DAP procedure is computationally more time-consuming than the NADP because the lateral load distribution should be updated, at each step of the DAP, based on an eigenvalue analysis.

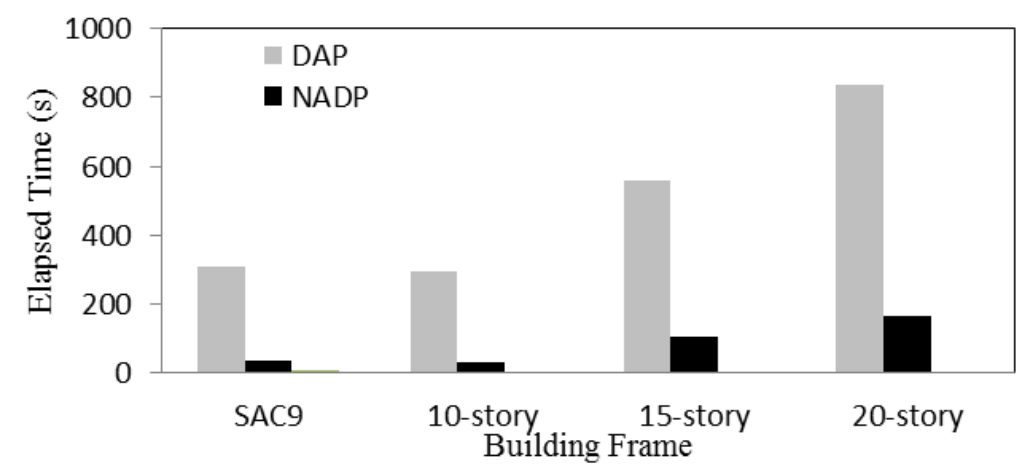

Fig. 10. The elapsed time for the fulfillment of the DAP and NADP procedures

As mentioned earlier, the NADP procedure uses the elastic modal characteristics of the structure to obtain the lateral load distribution. In such a way, changes in the modal properties of the structure are ignored. Therefore, it is important to evaluate the proposed procedure when the structure experiences large nonlinear deformations under increasing lateral loads during the pushover analysis. To investigate the accuracy of the proposed procedure in the case of large inelastic deformations, the records in Table 2 were once again scaled up to $1 \mathrm{~g}$. The error indices in the NADP procedure in estimating the story drifts and plastic hinge rotations of the 10-, 15-, and 20-story frames for the two intensity levels of $0.7 \mathrm{~g}$ and $1.0 \mathrm{~g}$ are shown in Fig. 11. Fig. 11a illustrates that the errors in the NADP, in estimating the story drifts for the intensity level of $1.0 \mathrm{~g}$, are slightly larger than those for the intensity level of $0.7 \mathrm{~g}$. However, the error indices are limited to 5\%. Furthermore, the errors in the plastic hinge rotations for the 10- and 15-story frames are slightly reduced when the intensity level increases to $1.0 \mathrm{~g}$ (see Fig. 11b). Therefore, the proposed procedure is accurate enough in estimating the seismic responses when the structure experiences more yielding.

Because the relative displacement between two successive floors is constant in the nonadaptive displacement-based pushover procedure, some important structural characteristics such as soft stories and weak stories can not be taken into consideration. Therefore, the accuracy of the proposed procedure may deteriorate when a weak/soft story deforms considerably into the inelastic range and the structure experiences local plastic mechanism in that story. Seismic evaluation of structures with these types of irregularities by means of the proposed procedure is beyond the scope of the current work. Work in this area is underway. Furthermore, the proposed procedure is being extended to three-dimensional asymmetric-plan building structures in which torsional effects are significant. 


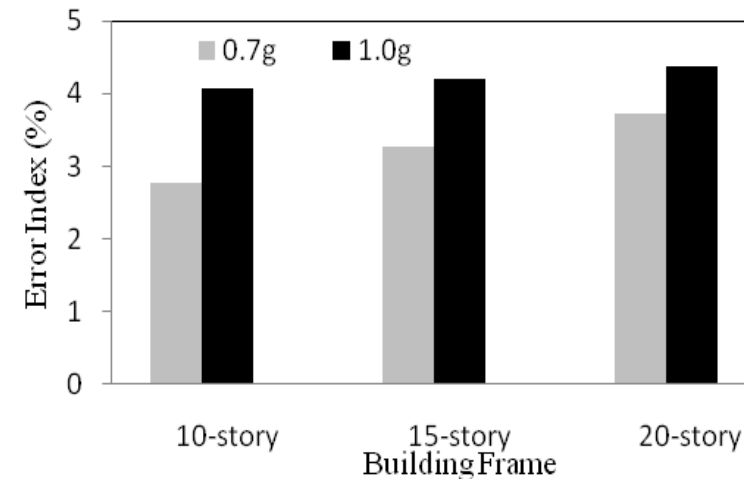

(a) Error indices in the story drifts

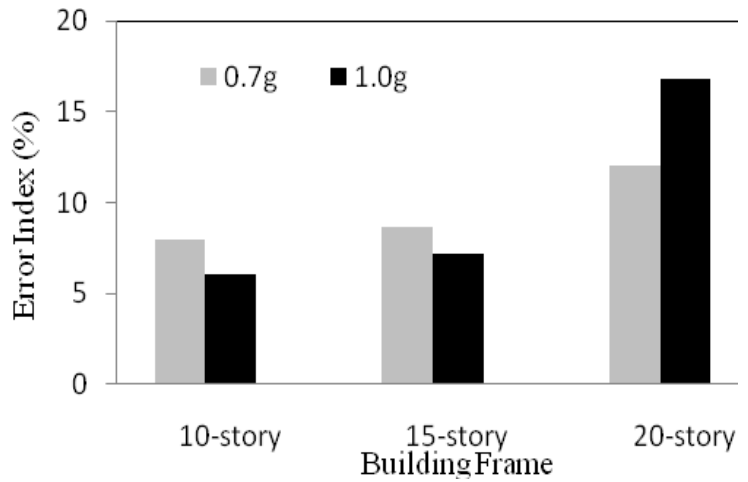

(b) Error indices in the plastic hinge rotations

Fig. 11. Error indices in the NADP procedure for the 10-, 15-, and 20-story frames for two intensity levels of $0.7 \mathrm{~g}$ and $1.0 \mathrm{~g}$

As previously described, a simple method was proposed to account for the effect of higher modes in the determination of the target displacement in a pushover analysis of tall buildings. The method can be used in conjunction with the NADP procedure. A comparison of the values of the target displacements derived from the proposed method and NL-RHA (for the intensity level of $0.7 \mathrm{~g}$ ) for the 10-, 15-, and 20-story frames is presented in Table 4. As can be seen in the table, the proposed method overestimates the target displacement in all cases, especially in the case of medium-rise buildings (i.e. 10- and 15-story frames). Moreover, it is noticeable that the error in the proposed method decreases with the increase in the height of the structure. The height-wise variation of the story drift ratios and plastic hinge rotations resulting from the NADP and NL-RHA for the 15-story frame are displayed in Fig. 12. The NADP was implemented considering the two values of the target displacement obtained by the proposed method and by the NL-RHA. The figure illustrates that the seismic demands are accurately estimated by the NADP at the lower stories when using the approximate target displacement obtained from the proposed method. The seismic responses are overestimated at the upper stories by up to $30 \%$. Therefore, the method proposed for the determination of the target displacement for tall building structures can be useful in performance-based seismic engineering.

Table 4. Target displacements obtained from the proposed method and from the NL-RHA for the intensity level of $0.7 \mathrm{~g}$

\begin{tabular}{cccc}
\hline \multirow{2}{*}{ Building Frame } & \multicolumn{2}{c}{ Target Displacement $(\mathrm{cm})$} & \multirow{2}{*}{ Error $(\%)$} \\
\cline { 2 - 3 } & Proposed Method & NL-RHA & \\
\hline 10 story & 35.12 & 28.60 & 22.8 \\
15 story & 38.85 & 33.58 & 15.7 \\
20 story & 42.36 & 38.40 & 10.3 \\
\hline
\end{tabular}




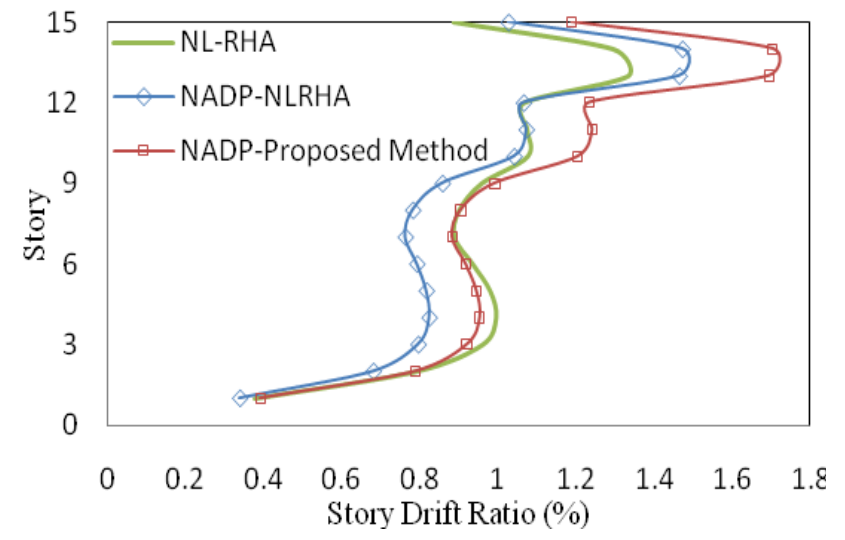

(a) Story drift ratios

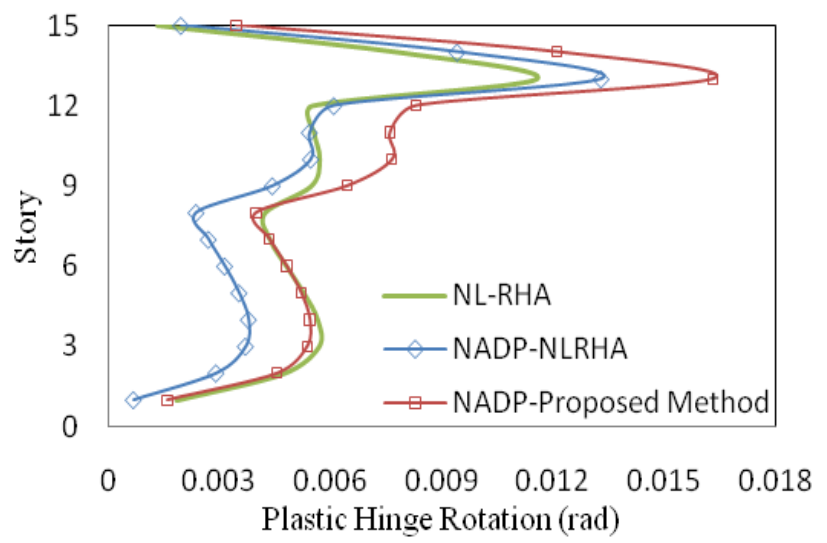

(b) Plastic hinge rotations

Fig. 12. The height-wise variation of the seismic demands obtained for the15-story frame

\section{Conclusions}

A non-adaptive displacement-based pushover (NADP) procedure was proposed to take the higher modes effect into account in estimating the seismic demands of tall building frames. The NADP procedure employs some single-run conventional and enhanced pushover analyses. The single-run conventional pushover analysis is performed using a displacement-based load pattern according to the first mode shape, while the single-run enhanced pushover analyses are carried out by the proposed lateral displacement distributions in this paper. The seismic demands are then predicted by enveloping the results obtained by the conventional and enhanced pushover analyses. The former analysis controls the responses at the lower stories of tall buildings, whereas the latter analysis (analyses) govern(s) at the upper stories.

The results illustrate that the MPA and NADP procedures predict the seismic responses with acceptable accuracy. The seismic demands are more accurately estimated by the MPA than by the NADP at the lower stories, while the NADP procedure provides better predictions of the seismic responses than the MPA at the upper stories of tall buildings in which the effect of higher modes is significant. The DAP procedure notably underestimates the story drift ratios and plastic hinge rotations at all stories of the frames. The enhanced lateral load distributions in the NADP procedure are calculated by algebraically adding the modal story displacements. Therefore, the sign of each modal displacement vector is preserved and the sign reversals in the lateral displacement distributions can be included. On the other hand, the signs of modal displacement vectors are suppressed in the DAP procedure due to the use of the SRSS combination rule. The DAP procedure is conceptually attractive, but it is time-consuming and sophisticated for application in structural engineering practice. The other advantage of the NADP procedure is that the NADP is implemented in a non-adaptive framework and does not require more computational effort and time cost.

To take the higher modes effect into account in the determination of the target displacement for tall building structures, a simple method was proposed using the response spectrum analysis (RSA). The target displacements are overestimated by this method, especially in the case of medium-rise buildings. The accuracy of the proposed method in the calculation of the target displacement is, however, acceptable for medium- and high-rise building frames. 
The results obtained for a very high intensity of ground motion records confirm that the seismic responses are accurately predicted by means of the NADP procedure when the structure undergoes large nonlinear deformations.

\section{Acknowledgement}

This research investigation was funded by the Iran National Science Foundation (INSF). This financial support is gratefully acknowledged.

\section{References}

Abbasnia, R., Davoudi, A. T., \& Maddah, M. M. (2013). An adaptive pushover procedure based on effective modal mass combination rule. Eng Struct 52: 654-666.

American Society of Civil Engineers. Seismic rehabilitation of existing buildings. ASCE standard No. ASCE/SEI 41-06, Reston; 2006.

Antoniou S, Pinho R (2004a) Advantages and limitations of adaptive and non-adaptive force-based pushover procedures. J Earthq Eng 8(4):497-522

Antoniou S, Pinho R (2004b) Development and verification of a displacement-based adaptive pushover procedure. J Earthq Eng 8(5):643-661

ATC (1996) Seismic evaluation and retrofit of concrete buildings. Report ATC-40. Redwood City (CA): Applied Technology Council

CEN. Pr-EN 1998-1 (2003) Eurocode 8: design of structures for earthquake resistance, part 1: final draft. European Committee for Standardization, Brussels (BEL)

Chopra AK (2001) Dynamics of structures. Theory and applications to earthquake engineering, 2nd edn. Prentice Hall, Englewood Cliffs, NJ

Chopra AK, Goel RK (2002) A modal pushover analysis procedure for estimating seismic demands for buildings. Earthq Eng Struct Dyn 31:561-582

Chopra AK, Goel RK (2004) A modal pushover analysis procedure to estimate seismic demands for unsymmetricalplan buildings. Earthq Eng Struct Dyn 33(8):903-927

Chopra AK, Goel RK, Chintanapakdee C (2004) Evaluation of a modified MPA procedure assuming higher modes as elastic to estimate seismic demands. Earthq Spectra 20(3):757-778

Fajfar P (2000) A nonlinear analysis method for performance based seismic design. Earthq Spectra 16(3):573-592

Ferraioli, M., Avossa, A. M., Lavino, A., \& Mandara, A. (2014). Accuracy of Advanced Methods for Nonlinear Static Analysis of Steel Moment-Resisting Frames. Open Construction and Building Technology Journal, 8(1), 310323.

FEMA (2000) Prestandard and commentary for the seismic rehabilitation of buildings. FEMA 356 Federal Emergency Management Agency, Washington (DC)

Jan TS, Liu MW, Kao YC (2004) An upper-bound pushover analysis procedure for estimating the seismic demands of high-rise buildings. Eng Struct 26:117-128

Kalkan E, Kunnath SK (2006) Adaptive modal combination procedure for nonlinear static analysis of building structures. J Struct Eng ASCE 132(11):1721-1731

Kim S-P, Kurama YC (2008) An alternative pushover analysis procedure to estimate seismic displacement demands. Eng Struct 30:3793-3807

Krawinkler H, Seneviratna GDPK (1998) Pros and cons of a pushover analysis of seismic performance evaluation. Eng Struct 20(4-6):452-462.

Kreslin M, Fajfar P (2011) The extended N2 method taking into account higher mode effects in elevation. Earthq Eng Struct Dyn. doi:10.1002/eqe.1104

Kunnath SK (2004) Identification of modal combination for nonlinear static analysis of building structures. ComputAided Civ Eng 19:246-259

Lopez-Menjivar MA, Pinho R (2004) A review of existing pushover methods for 2-D reinforced concrete buildings. Pavia (Italy): Rose School

Mwafy AM, Elnashai AS (2001) Static pushover versus dynamic analysis of R/C buildings. Eng Struct 23:407-424 
OpenSees (2014) Open system for earthquake engineering simulation. Pacific Earthquake Engineering Research Center, University of California, Berkeley CA. http://opensees.berkeley.edu/

Pecker A (2007) Advanced Earthquake Engineering Analysis, Springer, Wien.

Poursha M, Khoshnoudian F, Moghadam AS (2009) A consecutive modal pushover procedure for estimating the seismic demands of tall buildings. Eng Struct 31:591-599

Poursha M, Khoshnoudian F, Moghadam AS (2010) Assessment of modal pushover analysis and conventional nonlinear static procedure with load distributions of Federal Emergency Management Agency for high rise buildings. J Struct Des Tall Spec Build 19(3):291-308

Poursha M, Khoshnoudian F, Moghadam AS (2011) A consecutive modal pushover procedure for nonlinear static analysis of one-way unsymmetric-plan tall building structures. Eng Struct 33:2417-2434

Poursha M, Khoshnoudian F, Moghadam AS (2014) The extended consecutive modal pushover procedure for estimating the seismic demands of two-way unsymmetric-plan tall building structures under influence of two horizontal components of ground motions. J Soil Dyn Earthq Eng 63:162-173

Poursha M, Amini M A. (2015). A single-run multi-mode pushover analysis to account for the effect of higher modes in estimating the seismic demands of tall buildings. Bull. Earthq. Eng., 1-19.

Reyes JC, Chopra AK (2011) Three-dimensional modal pushover analysis of buildings subjected to two components of ground motion, including its evaluation for tall buildings. Earthq Eng Struct Dyn 40:789- 806

Shakeri K, Shayanfar MA, Kabeyasawa T (2010) A story shear-based adaptive pushover procedure for estimating seismic demands of buildings. Eng Struct 32:174-183

Sucuoglu H, Selim Gunay M (2011) Generalized force vectors for multi-mode pushover analysis. Earthq Eng Struct Dyn 40:55-74

Tso WK, Moghadam AS (1998) Pushover procedure for seismic analysis of buildings. Prog Struct Eng Mater 1(3):337-344 